\title{
PENERAPAN LATIHAN DEKODING PERSEPSI AUDITORI UNTUK MENSTIMULASI RESPON TERHADAP BUNYI PADA KLIEN DISAUDIA BILATERAL PROFOUND
}

\author{
Ami Rachmi, ${ }^{1 *}$, Yosrika ${ }^{2}$ \\ ${ }^{12}$ Politeknik Al Islam Bandung \\ rachmi_ami@yahoo.com
}

\begin{abstract}
ABSTRAK
Proses komunikasi akan terjadi jika setidaknya ada dua orang yang bertukar informasi melalui kode-kode yang disampaikan oleh pembicara dan juga kode-kode yang dimengerti oleh pendengar. Sementara itu, disaudia adalah hambatan bicara yang berkaitan langsung dengan hambatan pendengaran yang mengakibatkan penderitanya tidak mampu melakukan komunikasi verbal dengan baik. Penelitian ini bertujuan untuk mengetahui penerapan serta tingkat keberhasilan latihan dekoding persepsi auditori untuk menstimulasi respon terhadap bunyi pada seorang klien Disaudia Bilateral Profound. Metode penelitian yang digunakan adalah eksperimen SubjekTunggal. Pengumpulan data dilakukan melalui teknik wawancara yang dilakukan dengan orang tua klien, observasi secara langsung terhadap klien melalui pemeriksaan dan tes, serta studi dokumen rekam medis klien. Data yang telah terkumpul kemudian dianalisa untuk mendapatkan kesimpulan. Hasil dari penelitian menunjukkan bahwa setelah dilakukan terapi dengan menggunakan metode Latihan Dekoding menggunakan garpu tala dengan frekuensi $256 \mathrm{~Hz}, 341,3 \mathrm{~Hz}, 440 \mathrm{~Hz}$, dan $512 \mathrm{~Hz}$ sebanyak 20 kali pertemuan respon klien terhadap bunyi mengalami peningkatan. Pada tes awal klien mendapat 3 poin dan pada tes akhir klien mendapat 4 poin dengan presentase keberhasilan $37,5 \%$. Walaupun peningkatannya kurang signifikan dari hasil tersebut dapat disimpulkan bahwa penerapan latihan dekoding untuk meningkatkan respon terhadap bunyi pada klien disaudia bilateral profound dikatakan cukup berhasil karena pasien berhasil meningkatkan kemampuan pendengarannya pada frekuensi terendah $256 \mathrm{~Hz}$.
\end{abstract}

Kata kunci: auditori, dekoding, disaudia bilateral profound

\begin{abstract}
The communication process will occur if there are at least two people exchanging information through the codes conveyed by the speaker and also the codes understood by the listener. Meanwhile, dysaudia is a speech impediment that is directly related to hearing impairment resulting in the inability of the sufferer to communicate well verbally. This study aims to determine the implementation and success rate of auditory perception decoding exercises to improve response to sound on a Bilateral Profound Disaudia client. This research used a single-subject experiment. Data were collected through techniques of interview to the client's parents, direct observation of the client, and study of the client's medical record document. The collected data were then analyzed to draw conclusions. Results of the study showed that after 20 meetings of therapy using the Decoding Exercise method through the frequency of $256 \mathrm{~Hz}, 341,3$ $\mathrm{Hz}, 440 \mathrm{~Hz}$, and $512 \mathrm{~Hz}$ the ability of the client response toward sound increased from 3 in the initial test to 4 in the final test with a success percentage of $37.5 \%$. Based on
\end{abstract}


the results, it can be concluded that the application of decoding exercises to improve the response to sound on the profound bilateral dysaudia client is quite successful.

Keywords: auditory, decoding, bilateral profound

\section{PENDAHULUAN}

Sebagai bagian dari masyarakat, manusia ditakdirkan menjadi makhluk sosial yang membutuhkan interaksi yang diaktualisasikan melalui praktek komunikasi dengan manusia lainnya. Dalam Kamus Besar Bahasa Indonesia kata 'komunikasi' dijelaskan sebagai "pengiriman dan penerimaan pesan atau berita antara dua orang atau lebih sehingga pesan yang dimaksud dapat dipahami; hubungan; kontak". Dalam komunikasi, bahasa menjadi media yang mempermudah manusia memahami informasi. Bahasa yang digunakan dapat berupa bahasa verbal (lisan) maupun bahasa nonverbal (tulisan, isyarat/tanda). Bahasa membuat pemberi pesan dapat menyampaikan gagasan atau idenya kepada penerima pesan sehingga keduanya dapat saling memahami pesan yang dimaksudkan. Pada penggunaan bahasa verbal, komunikasi terjadi antara pembicara dan pendengar.

Kemampuan berbicara seseorang akan sangat tergantung pada kemampuannya mendengarkan bahasa orang lain dengan baik. Karenanya, organ pendengaran yang dimiliki harus berfungsi dengan maksimal. Apabila organ tersebut tidak berfungsi dengan baik, maka ia akan mengalami kesulitan untuk memahami bunyi bahasa yang disampaikan dan selanjutnya akan mempengaruhi komunikasi dengan lingkungannya. Kesulitan komunikasi akibat adanya hambatan pada organ pendengaran dikenal dengan istilah tuli atau tunarungu atau disebut juga disaudia. Secara sederhana disaudia dapat diartikan sebagai gangguan bicara akibat gangguan pendengaran (Stach, 2003:87). Sementara Donald F. Mores dalam Winarsih (2007: 22) mendefinisikan tunarungu sebagai suatu istilah umum yang menunjukkan kesulitan mendengar dari yang ringan sampai berat dan diklasifikasikan ke dalam tuli dan kurang dengar (Rini, 2014:2-3).

Berdasarkan kerusakan organnya, gangguan pendengaran dibagi menjadi tiga yaitu Conductive Hearing Loss (CHL), Sensorineural Hearing Loss (SNHL) dan Mixed Hearing Loss (MHL). CHL merupakan penurunan pendengaran yang disebabkan karena adanya gangguan pada fungsi tulang pendengaran. Kondisi ini bisa terjadi pada klien yang mengalami otitis media (radang telinga tengah), perforasi membran timpani, dan kerusakan tulang pendengaran. Pasien yang mengalami kondisi ini biasanya masih bisa mendengar suara, namun terdengar lebih lemah. Sementara itu, SNHL merupakan gangguan pendengaran akibat penurunan fungsi saraf pendengaran yang disebabkan oleh hilangnya atau rusaknya sel saraf (sel rambut) di dalam rumah siput. Dan MHL merupakan gangguan kombinasi keduanya, di mana terjadi kerusakan di telinga luar atau tengah bersamaan dengan kerusakan pada telinga dalam.

Gangguan pendengaran yang dialami oleh seseorang berdampak pada kemampuan individu itu untuk memproduksi suara dan bahasa yang dapat berujung pada hambatan bicara karena ketidakmampuannya untuk berkomunikasi secara verbal. Hambatan ini dikenal sebagai disaudia. Kurangnya kemampuan berkomunikasi klien disaudia dapat mempengaruhi kualitas hidup mereka. Saat ini terapi yang dapat dilakukan klien disaudia sangat terbatas dipraktekkan oleh masyarakat karena akses yang terbatas dan biaya yang diperlukan cukup besar terutama dalam penyediaan alat bantu dengar sehingga gangguan komunikasi verbal ini tidak cukup mendapat perhatian. Beberapa metode ringan dapat digunakan untuk menstimulasi respon terhadap bunyi pada klien disaudia. Dalam penelitian ini akan diterapkan latihan Dekoding Persepsi Auditori untuk menstimulasi respon terhadap bunyi kepada salah satu klien di Rumah Sakit Umum Daerah R. Syamsudin S.H yang diketahui mengalami Disaudia Bilateral Profound yaitu gangguan pendengaran sangat berat pada kedua telinga. Latihan tersebut dipilih karena kondisi klien yang baru menggunakan Alat Bantu Mendengar (ABM). Diharapkan dengan latihan ini akan ada peningkatan kemampuan respon terhadap bunyi pada klien. Berdasarkan latar belakang permasalahan di atas, maka penulis 
merumuskan masalah pada penelitian ini yang berfokus pada bagaimana pengaruh penerapan Latihan Dekoding Persepsi Auditori pada peningkatan respon terhadap bunyi pada kasus Disaudia Bilateral Profound dan sejauhmana tingkat keberhasilan dari penerapan Latihan Dekoding Persepsi Auditori berpengaruh pada peningkatan respon terhadap bunyi pada kasus Disaudia Bilateral Profound.

Tujuan penelitian ini adalah untuk mendeskripsikan pengaruh penerapan Latihan Dekoding Persepsi Auditori dan tingkat keberhasilannya pada peningkatan respon terhadap bunyi untuk kasus Disaudia Bilateral Profound. Untuk mencapai tujuan tersebut digunakan data yang berkaitan dengan penerapan Latihan Dekoding Persepsi Auditori pada klien anak yang berusia 9 tahun. Hasil penelitian ini diharapkan dapat memperkaya khasanah keilmuan terapi wicara, dapat meningkatkan kemampuan para terapis wicara, dan dapat membantu pada kegiatan penanganan klien disaudia khususnya pada kasus Disaudia Bilateral Profound.

\section{METODOLOGI PENELITIAN}

Penelitian ini merupakan penelitian kuantitatif dengan pendekatan eksperimen. Variasi jenis penelitian eksperimen ini menggunakan eksperimen subjek-tunggal yaitu seorang klien anak perempuan berusia 9 tahun 6 bulan di RSUD R Syamsudin S H. Desain penelitian subjek-tunggal ini menggunakan desain A-B-A, dengan A awal yaitu hasil sebelum diberikan perlakuan, B yaitu perlakuan yang diberikan kepada subjek, dan A akhir yaitu hasil setelah diberikan perlakuan selama terapi selama 5 kali pertemuan. Beberapa teknik yang digunakan dalam pengumpulan data adalah wawancara; observasi motorik, sensorik, dan bahasa bicara klien, berbagai tes, dan studi dokumen. Teknik pengumpulan data selama penelitian berlangsung secara lengkap dapat dilihat pada tabael 1 dibawah ini.

Tabel 1 Teknik, Instrumen Responden dan Indikator Penelitian

\begin{tabular}{|c|c|c|c|c|}
\hline No. & $\begin{array}{c}\text { Teknik } \\
\text { Pengumpulan } \\
\text { Data }\end{array}$ & Instrumen & Responden & Indikator \\
\hline 1. & Wawancara & $\begin{array}{l}\text { Format } \\
\text { Wawancara dan } \\
\text { Inform Consent }\end{array}$ & Keluarga klien & $\begin{array}{l}\text { Memperoleh data mengenai: } \\
\text { Identitas klien, faktor penyebab, } \\
\text { Riwayat Kesehatan sebelum dan } \\
\text { sesudah sakit, Riwayat penyakit } \\
\text { keluarga }\end{array}$ \\
\hline 2. & Observasi & Format observasi & Klien & $\begin{array}{l}\text { Mengetahui: Kondisi fisik, } \\
\text { kemampuan motorik, kemampuan } \\
\text { sensorik, kemampuan bahasa bicara } \\
\text { klien. }\end{array}$ \\
\hline 3. & $\begin{array}{l}\text { Pemeriksaan } \\
\text { alat wicara } \\
(\text { PAW) }\end{array}$ & Format Tes PAW & Klien & $\begin{array}{l}\text { Mengetahui struktur dan fungsi } \\
\text { organ bicara dan ada atau tidaknya } \\
\text { kerusakan pada organ bicara klien } \\
\text { baik secara anatomi maupun secara } \\
\text { fisiologisnya. }\end{array}$ \\
\hline 4. & $\begin{array}{l}\text { Pemeriksaan } \\
\text { Kemampuan } \\
\text { Wicara (PKW) }\end{array}$ & Format Tes PKW & Klien & $\begin{array}{l}\text { Mengetahui kemampuan wicara } \\
\text { klien pada tingkat vokal, konsonan, } \\
\text { dan suku kata. }\end{array}$ \\
\hline
\end{tabular}




\begin{tabular}{|c|c|c|c|c|}
\hline 5. & Tes Artikulasi & $\begin{array}{l}\text { Format Tes } \\
\text { Artikulasi }\end{array}$ & Klien & $\begin{array}{l}\text { Mengetahui kemampuan artikulasi } \\
\text { pada tingkat kata dan untuk menilai } \\
\text { ada atau tidaknya Substitusi, Omisi, } \\
\text { Distorsi, dan Adisi (SODA). }\end{array}$ \\
\hline 6. & $\begin{array}{l}\text { Tes Deteksi } \\
\text { Dini Gangguan } \\
\text { Komunikasi dan } \\
\text { Berbahasa } \\
\text { (DDGKB) }\end{array}$ & $\begin{array}{l}\text { Format Tes } \\
\text { DDGKB }\end{array}$ & Klien & $\begin{array}{l}\text { Mengetahui tingkat kemampuan } \\
\text { berko- munikasi pada klien apakah } \\
\text { sesuai usia kalendernya atau tidak. }\end{array}$ \\
\hline 7. & $\begin{array}{l}\text { Tes Pemahaman } \\
\text { Bahasa Secara } \\
\text { Auditori } \\
\text { (PBSA) }\end{array}$ & Format Tes PBSA & Klien & $\begin{array}{l}\text { Mengetahui pemahaman bahasa } \\
\text { klien pada tingkat kata benda, kata } \\
\text { kerja, dan preposisi. }\end{array}$ \\
\hline 8. & Tes Suara & Format Tes Suara & Klien & $\begin{array}{l}\text { Mengetahui nada, kualitas, dan } \\
\text { kenyaringan pada klien. }\end{array}$ \\
\hline 9. & $\begin{array}{l}\text { Tes Irama } \\
\text { Kelancaran }\end{array}$ & $\begin{array}{l}\text { Format Tes Irama } \\
\text { Kelancaran }\end{array}$ & Klien & $\begin{array}{l}\text { Mengetahui ada atau tidaknya } \\
\text { perpanjangan, pengulangan, } \\
\text { penghentian serta penahanan pada } \\
\text { saat bercerita, bernyanyi, dan } \\
\text { berhitung. }\end{array}$ \\
\hline 10. & Tes DQ & Format Tes DQ & Klien & $\begin{array}{l}\text { Mengetahui latelarisasi dominan } \\
\text { pada klien }\end{array}$ \\
\hline 11. & $\begin{array}{l}\text { Anamnesa } \\
\text { Makan dan } \\
\text { Minum }\end{array}$ & $\begin{array}{l}\text { Format Anamnesa } \\
\text { Makan dan } \\
\text { Minum }\end{array}$ & Keluarga klien & $\begin{array}{l}\text { Mengetahui apakah terdapat } \\
\text { gangguan pada fungsi mengunyah } \\
\text { dan menelan pada klien. }\end{array}$ \\
\hline 12. & Studi Dokumen & $\begin{array}{l}\text { Hasil } \\
\text { pemeriksaan } \\
\text { dokter }\end{array}$ & Dokter & $\begin{array}{l}\text { Data penunjang yang dibutuhkan } \\
\text { penulis dalam menguatkan data yang } \\
\text { diperoleh. }\end{array}$ \\
\hline 13. & $\begin{array}{l}\text { Tes Awal dan } \\
\text { Tes Akhir }\end{array}$ & $\begin{array}{l}\text { Format Tes Awal } \\
\text { dan Tes Akhir }\end{array}$ & Klien & $\begin{array}{l}\text { Mengetahui keberhasilan terapi yang } \\
\text { dicapai. }\end{array}$ \\
\hline
\end{tabular}

Sumber: Data Primer, 2019

Setelah data terkumpul, berdasarkan hasil wawancara, observasi dan tes serta studi dokumen, kemudian disusun program terapi yang terbagi menjadi program terapi jangka pendek dan jangka Panjang dengan menggunakan garpu tala yang mudah diketahui frekuensinya. Program terapi jangka pendek meliputi latihan meningkatkan kemampuan mendengar menggunakan garpu tala dengan frekuensi $256 \mathrm{~Hz}, 341,3 \mathrm{~Hz}, 440 \mathrm{~Hz}$, dan $512 \mathrm{~Hz}$ dengan tujuan menstimulasi kemampuan persepsi bunyi klien hingga dapat merespon bunyi pada frekuensi yang ditentukan menggunakan garpu tala. Program terapi jangka panjang meliputi latihan kemampuan mendengar pada frekuensi yang ditentukan dengan menggunakan garpu tala dan latihan membedakan bunyi-bunyi yang ada di lingkungan. Terapi ini bertujuan menstimulasi kemampuan persepsi bunyi klien dengan merespon bunyi pada frekuensi yang ditentukan serta meningkatkan kemampuan persepsi bunyi klien dengan membedakan macam-macam bunyi yang ada (tanpa garpu tala).Data yang terkumpul kemudian dijadikan landasan oleh penulis dalam penyusunan rancangan pelaksanaan terapi yang akan diberikan kepada klien. Terapi diberikan kepada klien selama 45 menit untuk 20 pertemuan terapi. Rincian pelaksanaan terapi dapat dilihat pada tabel 2 di bawah ini. 


\section{Tabel 2. Pelaksanaan Terapi}

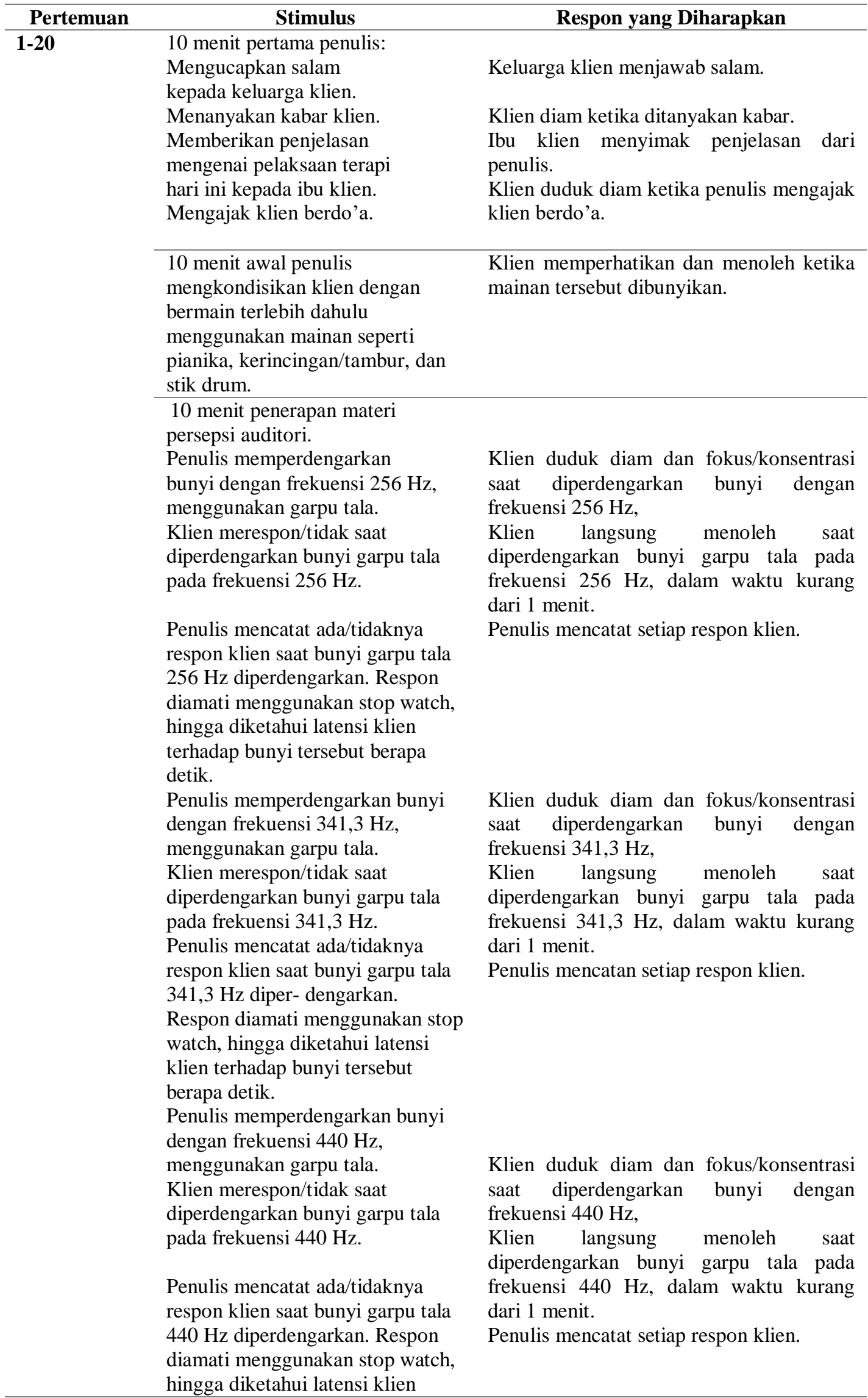




\begin{tabular}{|c|c|c|}
\hline & $\begin{array}{l}\text { terhadap bunyi tersebut berapa } \\
\text { detik. } \\
\text { Penulis memperdengarkan bunyi } \\
\text { dengan frekuensi } 512 \mathrm{~Hz} \text {, } \\
\text { menggunakan garpu tala. } \\
\text { Klien merespon/tidak saat } \\
\text { diperdengarkan bunyi garpu tala } \\
\text { pada frekuensi } 512 \mathrm{~Hz} \text {. } \\
\text { Penulis mencatat ada/tidaknya } \\
\text { respon klien saat bunyi garpu tala } \\
512 \text { Hz diperdengarkan. Respon } \\
\text { diamati menggunakan stop watch, } \\
\text { hingga diketahui latensi klien } \\
\text { terhadap bunyi tersebut berapa } \\
\text { detik. }\end{array}$ & $\begin{array}{l}\text { Klien duduk diam dan fokus/konsentrasi } \\
\text { saat diperdengarkan bunyi dengan } \\
\text { frekuensi } 512 \mathrm{~Hz} \text {, } \\
\text { Klien langsung menoleh saat } \\
\text { diperdengarkan bunyi garpu tala pada } \\
\text { frekuensi } 512 \mathrm{~Hz} \text {, dalam waktu kurang } \\
\text { dari } 1 \text { menit. } \\
\text { Penulis mencatat setiap respon klien. }\end{array}$ \\
\hline & $\begin{array}{l}5 \text { menit, penulis mengajak klien } \\
\text { untuk istirahat terlebih } \\
\text { dahulu. }\end{array}$ & Klien diharapkan beristirahat \\
\hline & $\begin{array}{l}5 \text { menit, penulis melanjutkan } \\
\text { kegiatan terapi dengan mengulang } \\
\text { latihan persepsi auditori. }\end{array}$ & $\begin{array}{l}\text { Klien dapat melanjutkan kegiatan terapi } \\
\text { untuk mengulang kembali latihan persepsi } \\
\text { auditori. }\end{array}$ \\
\hline & $\begin{array}{l}5 \text { menit, penulis memberitahu } \\
\text { kepada klien bahwa kegiatan } \\
\text { terapi telah selesai dan mengajak } \\
\text { klien untuk berdo'a. Selain itu, } \\
\text { penulis memberikan saran kepada } \\
\text { orang tua klien untuk melakukan } \\
\text { stimulasi persepsi bunyi kepada } \\
\text { klien dengan bunyi-bunyi yang } \\
\text { ada di sekitar lingkungan. }\end{array}$ & $\begin{array}{l}\text { Klien mengakhiri proses terapi dengan } \\
\text { sikap baik dan tenang saat berdo'a. Selain } \\
\text { itu orang tua klien juga dapat menyimak } \\
\text { dan juga mengikuti saran yang diberikan } \\
\text { oleh penulis. }\end{array}$ \\
\hline 21 & Evaluasi & Terdapat peningkatan. \\
\hline
\end{tabular}

Data dan hasil terapi yang terkumpul kemudian dianalisis untuk mendapatkan suatu kesimpulan yang komprehensif. Penulis membuat kriteria keberhasilan untuk keseluruhan jumlah tes yang diajukan penulis sebanyak 4 item untuk kemampuan persepsi auditori menggunakan garpu tala dengan poin maksimal yang harus dicapai adalah 8 poin. Penilaian kriteria keberhasilan terapi dilihat dari hasil tes awal dan tes akhir, apakah ada peningkatan pada latihan dekoding persepsi auditori untuk meningkatkan respon terhadap bunyi atau tidak. Kriteria keberhasilan dibagi menjadi 3 yaitu berhasil, cukup berhasil, dan tidak berhasil. Perhitungan evaluasi dalam menentukan skala keberhasilan sebagai berikut.

Penentuan skala presentase nilai hasil tes awal yaitu dengan rumus:

$$
\frac{\text { Nilai Hasil Tes Awal }}{\text { Jumlah Poin Maksimal }} \times 100 \%
$$

Penentuan skala presentase nilai hasil akhir yaitu dengan rumus:

$$
\frac{\text { Nilai Hasil Tes Akhir }}{\text { Jumlah Poin Maksimal }} \times 100 \%
$$


Penilaian perkembangan klien yaitu dengan rumus:

$$
\text { (Jumlah Nilai Hasil Tes Akhir - Jumlah Nilai Hasil Tes Awal) }
$$

Penentuan presentase skala keberhasilan peningkatan pada klien yaitu dengan rumus:

$$
\text { Presentase Tes Akhir - Presentase Tes Awal }
$$

Penentuan skala presentase keberhasilan keseluruhan yaitu dengan rumus:

$$
\frac{\text { Nilai Hasil Tes Awal - Nilai Hasil Tes Awal }}{\text { Jumlah Poin Maksimal - Nilai Hasil Tes Awal }} \times 100 \%
$$

Penentuan kriteria keberhasilan terapi disesuaikan dengan kriteria keberhasilan yang ditunjukkan pada tabel di bawah ini.

Tabel 3. Kriteria Keberhasilan

\begin{tabular}{cccc}
\hline No & Kenaikan Respon Benar & Skala presentase & Skala keberhasilan \\
\hline $\mathbf{1}$ & $0-1$ & & \\
\hline $\mathbf{2}$ & $2-3$ & $40 \%-60 \%$ & Tidak berhasil \\
\hline $\mathbf{3}$ & $4-5$ & $80 \%-100 \%$ & Cukup Berhasil \\
\hline
\end{tabular}

\section{HASIL DAN PEMBAHASAN}

Hasil wawancara dengan ibu klien didapatkan informasi yang berkaitan dengan faktor-faktor penyebab kelainan. Pada saat kehamilan 7 bulan, ibu klien (27 tahun) dirawat karena Demam Berdarah Dengue (DBD) yang menyebabkan sang ibu kekurangan cairan di dalam tubuh, demam yang tidak terlalu tinggi, muncul bintik-bintik merah di sekujur tubuhnya, dan peradangan pada selaput lendir. Dari riwayat persalinan ibu didapatkan informasi bahwa ibu melahirkan pada usia kehamilan 9 bulan lebih 1 minggu dibantu oleh bidan di klinik bersalin secara normal dan spontan, namun klien yang lahir dengan berat 2.70 gram dan panjang $43 \mathrm{~cm}$ setelah jarak waktu 1 menit kelahiran baru menangis. Pada usia 1 minggu setelah dilahirkan, klien didiagnosa mengalami katarak pada kedua matanya dan menjalani operasi serta memakai kacamata plus. Di usia 3 bulan klien didiagnosa mengalami kebocoran pada jantung sebelah kiri, sehingga klien perlu menjalani penanganan dan perawatan dengan pemasangan ring. Pada usia 6 bulan klien mengoceh seperti bayi pada umumnya. Namun, setelah memasuki usia 9 bulan klien cenderung diam dan tidak banyak mengoceh. Pada saat itu orang tua klien belum menyadari perubahan yang dialami oleh klien. Pada usia 3 tahun ibu baru menyadari bahwa klien terkesan tidak merespon ucapannya. Pada usia 6 tahun dilakukan beberapa pemeriksaan pendengaran di RSUP dr. Hasan Sadikin Bandung kepada klien, diantaranya adalah tes Otoacoustic Emissions (OAE) yaitu, terdapat gangguan dengar perifer pada kedua telinga, tes Brainstem Evoked Response Auditory (BERA) yaitu, telinga kanan $95 \mathrm{~dB}$ dan telinga kiri $105 \mathrm{~dB}$, dan tes Timpanogram yaitu, gangguan pendengaran perifer derajat sangat berat (profound) bilateral. Selain itu, klien juga melakukan Terapi Wicara selama \pm beberapa bulan. Pada usia 9 tahun klien mendapatkan Alat Bantu Mendengar (ABM).

Berdasarkan hasil wawancara, observasi, tes, dan studi dokumen diperoleh data mengenai keadaan atau kemampuan klien mengenai bicara, bahasa, suara, irama kelancaran, makan, dan minum. Untuk sindroma yang berhubungan dengan kemampuan wicara klien diketahui bahwa klien melewati refleksif vokalisasi pada usia 0-3 bulan dan babbling pada usia 4-6 bulan. Klien belum dapat berbahasa benar pada usianya sekarang 9 tahun 6 bulan. Berdasarkan Pemeriksaan Alat Wicara (PAW) di mana penilaian dilakukan pada struktur dan fungsi dari organ wicara klien seperti bibir, gigi, lidah, langit-langit keras, langit-langit lembut, Fauces, dan Nasal Cavities didapat hasil 
bahwa seluruh struktur organ wicara dalam keadaan baik dan sebagian besar dapat berfungsi walaupun ada beberapa kelemahan yang ditemukan seperti pada bibir tidak merespon ucapan /pa/, pada lidah tidak merespon saat diperintah menyentuh alveolar dan langit-langit lembut dalam 5 detik tiga kali pelaksanaan, dan tidak merespon saat diperintah untuk memproduksi /ta/, /ka/, dan /ca/ dalam 5 detik dengan tiga kali pelaksanaan. Pada Langi-langit keras tidak terdapat fistula di palatum dan juga celah di alveolar, dan tidak terlihat Pharyngeal flap. Berdasarkan pergerakan organ yang disengaja yang diteskan pada klien dengan 20 item tes, klien dapat melaksanakan sebanyak 16 gerakan. Klien tidak merespon saat diminta menirukan gerakan seperti bersiul, mendehak, mendecak, dan melakukan gerakan seperti orang kedinginan. Hasilnya pergerakan organ yang disengaja berada pada skala 4, yaitu sama dengan skala 8-tugas/perintah yang diberikan dapat dilaksanakan dengan tepat, langsung (tanpa mencoba-coba)-tetapi diberi contoh oleh penguji. Sementara itu, hasil Pemerikasaan Kemampuan Wicara (PKW) menunjukkan bahwa pada tingkat suku kata dan kata klien tidak dapat merespon dikarenakan klien belum dapat berbahasa secara verbal meski usianya sudah 9 tahun 6 bulan. Bahasa yang diucapkan oleh klien masih belum mengandung makna.

Hasil test Deteksi Dini Gangguan Komunikasi Berbahasa (DDGKB) menjelaskan pemahaman lisan dan kemampuan lisan klien berada pada usia jauh di bawah usia idealnya di mana klien tidak dapat memahami bunyi- bunyi atau suara-suara dan perintah, dan tidak dapat mengeluarkan bunyi atau suara yang bukan reflek serta pengembangannya. Sementara itu hasil tes Pemahaman Bahasa Secara Auditori (PBSA) menunjukkan bahwa klien tidak merespon rangsangan dikarenakan fungsi dari auditori klien terganggu dan modalitas pemahaman klien baru sampai pada tahap mencocokan. Berkenaan dengan suara, irama kelancaran, dan menelan, klien dapat memberikan respon suara yang terdengar nyaring tetapi tidak bermakna, klien tidak dapat merespon dengan baik dikarenakan keterbatasan dalam perbendaharaan kata. Walaupun demikian, kemampuan menelan klien berfungsi dengan baik yang ditunjukkan dengan makan normal 3 kali sehari dan mampu minum air putih menggunakan gelas, minum teh menggunakan sedotan, dan makan makanan padat menggunakan sendok dalam waktu yang normal.

Hasil observasi lain yang relevan memperlihatkan bahwa secara umum, kondisi fisik klien baik. Klien terkadang memakai $\mathrm{ABM}$ dan kacamata. Klien tidak memakai kursi roda maupun tongkat untuk berjalan. Perkembangan motorik kasar klien saat ini menunjukkan kemampuan untuk dapat berjalan, berlari, menari, dan juga melompat-lompat dengan kemampuan motorik halusnya yang mampu menggunakan pensil untuk mencoret-coret kertas, menulis, dan juga mewarnai.

Pengamatan kemampuan sensorik meliputi beberapa aspek, seperti kemampuan pendengaran, visual, dan taktil. Kemampuan S1 (pendengaran) klien berfungsi kurang baik, berdasarkan hasil pengamatan klien dapat menoleh jika dipanggil namanya dengan bantuan ABM. Kemampuan S2 (visual) klien bekerja kurang baik, klien mampu melihat benda di sekitarnya dengan menggunakan alat bantu berupa kacamata. Kemampuan S3 (taktil) klien juga bekerja kurang maksimal. Klien bisa merasakan sentuhan halus dan kasar, panas dan dingin, tetapi tidak mampu membedakan sentuhan tersebut. Untuk aspek koordinasi visiomotor, klien mampu menyusun balok secara vertikal dan horizontal, mampu mencocokan gambar yang sama, dan mampu memasukan berbagai bentuk balok kayu sesuai dengan bentuknya ke dalam kotak.

Berdasarkan hasil observasi terhadap kesan intelegensia pada klien, diperoleh data bahwa klien belum dapat mengenali, memahami, dan membedakan bunyi-bunyi di lingkungan sekitar dan belum dapat mengenali anggota tubuhnya dengan baik sehingga mempengaruhi emosinya yang belum stabil. Walaupun demikian klien tidak mengalami kesulitan dalam bersosialisasi di lingkungannya, klien dapat bermain dengan teman seusianya di luar rumah. 
Hasil evaluasi kemampuan awal sebelum terapi dan kemampuan akhir setelah diberikan terapi sebanyak 20 kali pertemuan dijelaskan pada tabel 4.

Tabel 4. Hasil Evaluasi Kemampuan Klien

\begin{tabular}{|c|c|c|c|c|c|c|c|c|c|}
\hline \multirow[t]{2}{*}{ No } & \multirow{2}{*}{$\begin{array}{c}\text { Frekuensi } \\
\text { Garpu Tala }\end{array}$} & \multicolumn{3}{|c|}{ Respon Bunyi } & \multirow[t]{2}{*}{ No } & \multirow{2}{*}{$\begin{array}{c}\text { Frekuensi } \\
\text { Garpu Tala }\end{array}$} & \multicolumn{3}{|c|}{ Respon Bunyi } \\
\hline & & TM & $\mathrm{CM}$ & $\mathrm{M}$ & & & TM & $\mathrm{CM}$ & $\mathrm{M}$ \\
\hline 1 & $256 \mathrm{~Hz}$ & 0 & - & - & 1 & $256 \mathrm{~Hz}$ & - & 1 & - \\
\hline 2 & $341,3 \mathrm{~Hz}$ & - & 1 & - & 2 & $341,3 \mathrm{~Hz}$ & - & 1 & - \\
\hline 3 & $440 \mathrm{~Hz}$ & - & 1 & - & 3 & $440 \mathrm{~Hz}$ & - & 1 & - \\
\hline 4 & $512 \mathrm{~Hz}$ & - & 1 & - & 4 & $512 \mathrm{~Hz}$ & - & 1 & - \\
\hline & Jumlah & - & 3 & - & & Jumlah & - & 4 & - \\
\hline
\end{tabular}

Keterangan:

TM: Tidak Mampu, klien diberikan nilai 0 apabila tidak menoleh ketika diberikan stimulasi bunyi secara berulang-ulang dalam waktu 1 menit.

CM:Cukup Mampu, klien diberikan nilai 1 apabila menoleh ketika diberikan stimulasi bunyi secara berulang-ulang dalam waktu 1 menit.

M: Mampu, klien diberikan nilai 2 apabila mampu menoleh dengan spontan/langsung ketika diberikan stimulasi bunyi.

Tabel 4 menjelaskan hasil tes akhir yang didapat dari klien dibandingkan dengan hasil tes awal dan kemudian digunakan sebagai bahan evaluasi. Dari hasil tes awal persepsi bunyi klien mendapatkan skor 3 poin dari jumlah 4 item frekuensi yaitu: $256 \mathrm{~Hz}, 341,3 \mathrm{~Hz}, 440 \mathrm{~Hz}$, dan $512 \mathrm{~Hz}$. Sedangkan hasil tes akhir klien mendapatkan skor 4 poin (dari nilai maksimal 8 poin). Dari hasil tersebut, diketahui bahwa klien mengalami peningkatan skor sebanyak 1 poin.

Peningkatan perbandingan sebelum dan sesudah terapi ditentukan dengan penghitungan menggunakan rumus:

$$
\begin{aligned}
& \text { (Jumlah Nilai Hasil Tes Akhir - Jumlah Nilai Hasil Tes Awal) } \\
& 4-3=1
\end{aligned}
$$

Berdasarkan penghitungan hasil tes akhir dan tes awal diketahui bahwa klien memperoleh peningkatan 1 poin.

Untuk menentuan skala keberhasilan, nilai tes awal digunakan dengan penghitungan menggunakan rumus:

$$
\frac{\text { Nilai Hasil Tes Awal }}{\text { Jumlah Poin Maksimal }} \times 100 \%=\frac{3}{8} \times 100 \%=37,5 \%
$$

Nilai tes akhir juga digunakan dengan penghitungan sebagai berikut:

$$
\frac{\text { Nilai Hasil Tes Akhir }}{\text { Jumlah Poin Maksimal }} \times 100 \%=\frac{4}{8} \times 100 \%=50 \%
$$

Peningkatan kemampuan respon klien terhadap bunyi dapat diketahui dengan perhitungan antara tes awal dan tes akhir dengan rumus:

$$
\frac{\text { Nilai Hasil Tes Akhir-Nilai Hasil Tes Awal }}{\text { Jumlah Poin Maksimal-Nilai Hasil Tes Awal }} \times 100 \%=\frac{4-3}{8-3} \times 100 \%=20 \%
$$

Hasil penghitungan presentase keberhasilan terapi dekoding persepsi auditori kemudian disesuaikan dengan kriteria keberhasilan yang telah penulis tentukan. Berikut adalah kriteria keberhasilan yang penulis tentukan. 
Tabel 5. Kriteria Keberhasilan

\begin{tabular}{cccc}
\hline No & $\begin{array}{c}\text { Kenaikan Respon } \\
\text { Benar }\end{array}$ & Skala Presentase & Skala Keberhasilan \\
\hline $\mathbf{1}$ & $0-1$ & $0 \%-20 \%$ & Tidak Berhasil \\
\hline $\mathbf{2}$ & $2-3$ & $40 \%-60 \%$ & Cukup Berhasil \\
\hline $\mathbf{3}$ & $4-5$ & $80 \%-100 \%$ & Berhasil \\
\hline
\end{tabular}

Berdasarkan hasil tes di atas diketahui bahwa klien mengalami peningkatan dalam respon terhadap bunyi menggunakan garpu tala dengan frekuensi yang ditentukan sebanyak 1 poin dengan persentase $20 \%$.

\section{KESIMPULAN}

Berdasarkan hasil wawancara, observasi, pemeriksaan, tes kemampuan, serta studi dokumentasi rekam medis klien di rumah sakit, dapat disimpulkan bahwa klien mengalami kehilangan kemampuan pendengarannya diakibatkan oleh faktor-faktor yang terjadi pada masa kehamilan klien (pre-natal), saat klien dilahirkan (natal), dan setelah kelahiran (post-natal). Dari indikasi klinis yang diceritakan ibunya dapat disimpulkan bahwa sang ibu terkena virus TORCH ketika hamil yang menjadi penyebab kelainan kongenital pada organ pendengaran janin yang dikandungnya. Kelainan juga terjadi pada masa natal dan post-natal yang menyebabkan gangguan pendengarannya semakin berat.

Perbandingan hasil test awal dan akhir menunjukkan peningkatan yang kurang signifikan di mana terapi yang diberikan hanya mampu meningkatkan kemampuan mendengar pasien sebanyak 1 poin dengan persentase keberhasilan sebesar $37,5 \%$. Sehingga dapat dikatakan bahwa penerapan metode latihan dekoding persepsi auditori untuk menstimulasi respon terhadap bunyi pada klien disaudia bilateral profound dapat dikatakan tidak berhasil (20\%). Walaupun demikian, dengan adanya terapi latihan dekoding persepsi auditori dengan menggunakan garpu tala dapat menstimulasi respon klien terhadap bunyi garpu tala dengan frekuensi $256 \mathrm{~Hz}$ yang pada awal test tidak dapat didengar sama sekali oleh klien. Sehingga diharapkan apabila metode ini diberikan terus menerus kepada klien dapat menambah kemampuan mendengar klien.

Dengan hasil ini, diharapkan penelitian selanjutnya dapat dilakukan kepada klien dengan kasus yang sama dengan menggunakan metode yang berbeda untuk mendapatkan metode terbaik yang dapat diberikan untuk meningkatkan kemampuan mendengar klien disaudia bilateral profound secara maksimal.

\section{UCAPAN TERIMA KASIH}

Penulis ingin mengucapkan terima kasih dan penghargaan setinggi-tingginya kepada Jajaran Direksi Politeknik Al Islam Bandung, Kepala LPPM Politeknik Al Islam Bandung, Ketua Program Studi Terapi Wicara Politeknik Al Islam Bandung, klien dan keluarga klien, jajaran Rumah Sakit Umum Daerah R Syamsudin S H, serta seluruh pihak yang tidak bisa disebutkan satu persatu, atas segala bantuan baik materil maupun moril, dukungan serta motivasinya pada penelitian ini. Semoga menjadi amal sholeh dan Allah SWT membalas semua amal kebaikan yang telah diberikan dan semua memperoleh keberkahan dari-Nya. Aamiin. 


\section{DAFTAR PUSTAKA}

American Speech-Language-Hearing Association. (2011). Speech-Language Pathology Medical Review Guidelines. American Speech Language Hearing Association: Rockville

Depertemen Kesehatan RI. (2009). Promosi Kesehatan. Dipetik Juni 2019, 10, dari https://s3.amazonaws.com/academia.edu.documents/38193352/ ringkasanteskompetensibidangkementrienkesehatan 3. Pdf.

Estabrooks, W. (1994). Auditory Verbal Therapy for Parents and Professionals. Washington: Alexander Graham Bell Association for the Deaf.

Kadek, S. Darmadi. (2007). Gejala Rubela Bawaan (Kongenital) Berdasarkan Pemeriksaan Serologis dan RNA Virus. Indonesian Journal of Clinical Pathology and Medical Laboratory. 13(2); 6371. Dipetik Juni 2019, $10, \quad$ dari https://www.researchgate.net/publication/328279583_GEJALA_RUBELA_BAWAAN_KONG ENITAL_BERDASARKAN_PEMERIKSAAN_SEROLOGIS_DAN_RNA_VIRUS/link/5bf1a 592a6fdcc3a8ddfe244/downlo ad.

Legawati. (2018). Asuhan Persalinan dan Bayi Baru Lahir. Malang: Wineka Media.

Madyawati, Lilis. (2017). Strategi Pengembangan Bahasa pada Anak. Jakarta: Kharisma Putra Utama.

Paul, V.Peter., Whitelaw, Gail M. Hearing and Deafness: An Introduction for Health and Education Professionals. Massachusetts: Jones and Bartlett Publishers

Pranindyo, Ki. (2000). Metoda-metoda Terapi Bidang Artikulasi. Jakarta: Akademi Terapi Wicara (ATW).

Rini, Hapsari Puspa. (2014). Peningkatan Keterampilan Sosial Anak Tunarungu kelas VI SDLB Melalui Permainan Tradisional Pasaran di SLB-B Wiyata Dharma I Tempel. Fakultas Ilmu Pendidikan. Universitas Negeri Yogyakarta. Dipetik Mei 2019, 26, dari http://journal.student.uny.ac.id/ ojs/ojs/index.php/plb/article/download/6252/6004.

Rundjan, Lily., Amir, Idham., Suwento, Ronny., \& Mangunatmaja, Irawan. (2005). Skrining Gangguan Pendengaran pada Neonatus Risiko Tinggi. Sari Pediatri. 6(4); 149-154. Dipetik Juni 2019, 10, dari https://saripediatri.org /index.php/sari-pediatri/article/download/871/805.

Satari, Hindra I., dan Meilisari, Mila. (2008). Demam Berdarah: Perawatan di Rumah \& di Rumah Sakit. Jakarta: Puspa Swara.

Setyono, Bambang. (2000). Terapi Wicara. Jakarta: EGC.

Somantri, Sutjihati. (2005). Psikologi Anak Luar Biasa. Bandung: Refika Aditama.

Soepardi, A. Efianty., dan Iskandar, Nurbaeti. (2001). Telinga Hidung Tenggorok Leher. Jakarta: FKUI.

Soepardi, A. Efianty., dan Iskandar, Nurbaeti. (2012). Buku Ajar Ilmu Kesehatan Telinga Hidung Tenggorok Kepala \& Leher. Jakarta: FKUI.

Stach, Brad A. (2003). Comprehensive Dictionary of Audiology: Illustrated ( $2^{\text {nd }}$ ed). Canada: Delmar Learning.

Van Riper, Charles., and Erickson, Robert L. (1984). Speech Correction: An Introduction to Speech Pathology and Audiology. Needham Heights: Simon \& Schuster.

Weiss, Curtis E., Gordon, Mary E., \& Lillywhite, Herold S. (1987). Clinical Management of Articulatory and Phonologic Disorders. London: Williams \& Wilkins.

Winarsih, Murni. (2007). Intervensi Dini bagi Anak Tunarungu dalam Pemerolehan Bahasa. Jakarta: Depdiknas RI.

Wu, Cheng Ju Dora \& Brown, P. Margaret. (nd). Parents' and Teacher's Expectations of Auditory Verbal Therapy. The Volta Review. 104(1); 5-20. 